\title{
Ovarian follicular activity in Booroola lambs with and without a fecundity gene
}

\author{
K. P. McNatty, S. Lun, D. A. Heath and L. E. O'Keeffe \\ Wallaceville Animal Research Centre, Research Division, Ministry of Agriculture and Fisheries, \\ Private Bag, Upper Hutt, New Zealand
}

\begin{abstract}
Summary. The ovaries of 3-month-old Booroola lambs which were heterozygous carriers of a major gene (F) influencing the ovulation rate in mature ewes (i.e. $F+$ lambs) were compared to those of similarly-aged Booroola lambs which were noncarriers of the F-gene (i.e. ++ lambs). The ovaries of the $\mathrm{F}+$ Booroola lambs were significantly lighter $(P<0.01)$ than those of ++ lambs even though the mean \pm s.e.m. number of follicles ( $\geqslant 1 \mathrm{~mm}$ diam.) in the $\mathrm{F}+$ lambs was greater than that in the ++ lambs (i.e. $F+$ lambs, $30 \cdot 2 \pm 2 \cdot 5$ follicles; ++ lambs, $18.4 \pm 1 \cdot 2$ follicles; $P<0.01)$.
\end{abstract}

In granulosa cells from non-atretic follicles ( $\geqslant 1 \mathrm{~mm}$ diam.) from $\mathbf{F}+$ and ++ Booroola lambs, FSH (NIAMDD-FSH-S16) doses of 100 and $1000 \mathrm{ng} / \mathrm{ml}$ caused significant stepwise increases $(P<0.05)$ in cyclic adenosine $3^{\prime}, 5^{\prime}$-monophosphate (cAMP) production compared to that achieved at FSH doses of 0 and $1 \mathrm{ng} / \mathrm{ml}$ or at any FSH dose in cells from atretic follicles. However, no significant differences in FSH-induced cAMP production were noted with regard to Booroola genotype or follicular diameter.

None of the granulosa cell preparations from non-atretic follicles of $1-2.5 \mathrm{~mm}$ diameter from $F+$ lambs $(N=13)$ or from non-atretic follicles of $1-4.5 \mathrm{~mm}$ diameter from ++ lambs $(\mathrm{N}=16)$ responded to LH (NIAMDD-LH-S24; 10 or $1000 \mathrm{ng} / \mathrm{ml}$ ) to produce significantly more cAMP than did the controls. In contrast, the granulosa cell preparations from non-atretic follicles of 3-4.5 mm diameter from $F+$ lambs $(\mathrm{N}=4)$ and from non-atretic follicles of $\geqslant 5 \mathrm{~mm}$ diameter of ++ lambs $(\mathrm{N}=4)$ produced significantly more cAMP $(P<0.05)$ in response to $\mathrm{LH}(1000 \mathrm{and} / \mathrm{or} 10 \mathrm{ng} / \mathrm{ml})$ relative to that in the controls. The theca interna from follicles of lambs of both genotypes had functional LH receptors as judged by the androstenedione responses to exogenous LH although no genotypic differences were noted.

In $\mathrm{F}+$ lambs, the follicular fluid concentrations of testosterone but not oestradiol (i.e. in $1-4.5 \mathrm{~mm}$ diam. follicles) and granulosa cell aromatase activity (i.e. in 3-3.5 mm diam. follicles) were significantly higher (both $P<0.05$ ) than in corresponding follicles or cells from ++ lambs.

Collectively the results suggest that the Booroola F-gene influences the composition and function of sheep ovaries before puberty.

\section{Introduction}

Highly fecund Booroola ewes contain a major gene which influences their ovulation rate (see Bindon, 1984 for review). Homozygous (FF), heterozygous $(F+)$ and non-carriers $(++)$ of the putative $F$ gene have been segregated on the basis of at least one ovulation recording of $\geqslant 5,3$ or 4 and 1 or 2 respectively (Davis et al., 1982). In mature ewes (4-9 years) it has been established that the amounts of adenosine cyclic $3^{\prime}, 5^{\prime}$-monophosphate (cAMP) produced by the cells of small $(0.1-1.0 \mathrm{~mm}$ diam.) and larger-sized follicles $(>1-4.5 \mathrm{~mm}$ diam.) in response to follicle-stimulating 
hormone (FSH) and/or luteinizing hormone (LH) were significantly related to genotype $(\mathrm{FF}>\mathrm{F}+>++$; Henderson et al., 1985; McNatty et al., 1986a; K. M. Henderson, unpublished data). Moreover the 3-4.5 mm diameter follicles of F-gene carriers have peak concentrations of oestradiol in follicular fluid and granulosa cells with peak aromatase activity as well as functional receptors for human chorionic gonadotrophin (hCG)/LH (Henderson et al., 1985; McNatty et al., $1985,1986 \mathrm{~b}, \mathrm{c})$. In contrast, in ++ ewes, the peak concentrations of oestradiol in follicular fluid and granulosa cells with peak aromatase activity and functional hCG/LH receptors are not normally present until the follicles are $\geqslant 5 \mathrm{~mm}$ diameter. These differences between the genotypes may explain, at least in part, why follicles in FF and $\mathrm{F}+$ ewes ovulate at smaller diameters than those in ++ ewes (FF, 2-4.5 mm; F,$+ 3-5 \mathrm{~mm}$;,$++ 5-8 \mathrm{~mm}$ diam.) and why the mean weight of corpora lutea in Booroola ewes is inversely correlated to the ovulation rate (McNatty et al., 1986b).

There is some evidence that genotypic differences may also exist in the ovaries of Booroola lambs. At 30-45 days of age, Booroola-Merino ewe lambs had significantly higher plasma concentrations of FSH but not LH compared to non-Booroola-Merino ewe lambs (Bindon et al., 1985). Moreover, the ovulatory response to PMSG in 5-6-month-old Booroola lambs was also found to be influenced by genotype ( $\mathrm{FF}>\mathrm{F}+>++$; Davis \& Johnstone, 1985). At the ovarian level, the number of vesicular follicles in new-born Booroola lambs was significantly lower than that in new-born Merino controls (Tassell et al., 1983).

The aim of the present study was to compare some more detailed aspects of ovarian activity in $\mathrm{F}+$ and ++ Booroola lambs at 3 months of age to determine whether F-gene expression is evident in the ovaries of the sheep before puberty (i.e. several months before the first expected ovulation). A secondary aim of this study was to compare follicular activity in Booroola lambs with previously published data on Booroola ewes.

\section{Materials and Methods}

\section{Animals}

These were spring-born Booroola lambs $(\mathrm{N}=16++, \mathrm{N}=13 \mathrm{~F}+$ ) out of Romney ewes and all lambs were born within 10 days of one another. The lambs were sired by 4 progeny-tested interbred Booroola Merino $\times$ Romney rams. Under progeny test at the Invermay Agricultural Research Centre, the two FF rams had 30/33 and 33/36 daughters with ovulation-rates $\geqslant 3$ on at least one occasion after 4 laparoscopies. The two ++ rams had only $4 / 44$ and $2 / 31$ daughters with ovulations $\geqslant 3$ on at least one occasion after 4 laparoscopies. Subsequent extensive use of these rams at Invermay has confirmed these genotypes (G. Davis, personal communication). At exactly 3 months of age, all the lambs were weighed and their ovaries removed.

\section{Follicle dissection and classification}

Excised ovaries were weighed and their gross morphology recorded. With the aid of a stereomicroscope (Zeiss SV8; Oberkochen, West Germany; $\times 8-64)$ and variable mixtures of both incident and reflected fibre optic (i.e. cold but evenly distributed) light (Schott, Wiesbaden, West Germany), individual ovarian follicles $(\geqslant 0.1 \mathrm{~mm}$ diam.) are easily visualized in freshly isolated tissue. In this study, all individual antral follicles ( $\geqslant 1 \mathrm{~mm}$ diam.) were dissected free of extraneous tissue and their diameters recorded. The incidence of accidental follicular rupture before the diameters were recorded was negligible. The granulosa cells and theca interna of these follicles were recovered as described in detail elsewhere (McNatty et al., 1984a, b). Follicles were classified as non-atretic or atretic as described for Booroola ewes (McNatty et al., 1985, 1986b). In brief, a non-atretic follicle was one which contained a vascularized theca interna which was red, pink or white, no debris in follicular fluid, $\geqslant 25 \%$ of the expected maximum number of granulosa cells for a given follicle size and a healthy-looking oocyte. An atretic follicle was one in which one or more of the above criteria were not satisfied. For $\mathbf{F}+$ lambs the maximum number of granulosa cells in different sized follicles was based on that previously found for mature ewes (McNatty et al., 1985). For example, in follicles of 1, 2, 3, 4 and $5 \mathrm{~mm}$ diameter from $\mathrm{F}+$ lambs the maximum number of cells was assumed to be $1 \times 10^{6}, 2 \times 10^{6}, 2.6 \times 10^{6}$, $3.3 \times 10^{6}$ and $3.3 \times 10^{6}$ respectively. In ++ lambs, the maximum number in follicles of $1,2,3,4,5,6,7 \mathrm{~mm}$ diameter follicles was assumed to be $1.1 \times 10^{6}, 2.3 \times 10^{6}, 3.0 \times 10^{6}, 4.2 \times 10^{6}, 5.0 \times 10^{6}, 7 \times 10^{6}$ and $9.3 \times 10^{6}$ respectively. The viabilities of the cell populations from individual follicles were not determined. 
Determination of granulosa cell responsiveness to gonadotrophins and oestradiol-17 $\beta$ synthetase (aromatase) activity

From each lamb the granulosa cells from individual follicles were pooled with respect to follicular diameter $(1-2.5 \mathrm{~mm}, 3-4.5 \mathrm{~mm}, \geqslant 5 \mathrm{~mm}$ ) and follicular health (atretic or non-atretic). Each pooled sample of cells was split into 2 fractions, one to study the cellular responsiveness to gonadotrophins by measuring cAMP production, the other to study aromatase activity. The cells in dissection medium [Minimum Essential Medium with Earle's salts, Hepes buffer ( $20 \mathrm{mM}$ ), $1 \%$ bovine serum albumin (BSA; $96 \% \mathrm{w} / \mathrm{w}$ pure; Immuno-Chemical Products, Auckland, N.Z.) and gentamicin $(50 \mu \mathrm{g} / \mathrm{ml})$; Medium A] were centrifuged at $200 \mathrm{~g}$ for $15 \mathrm{~min}$ and resuspended in Dulbecco's phosphate-buffered saline $+0.1 \%$ BSA (DBS-BSA) for determining the cAMP response to gonadotrophins, or in Medium A $+\mathrm{L}-$ glutamine $(0.2 \mathrm{~g} / \mathrm{l})+$ sodium bicarbonate $(0.85 \mathrm{~g} / 1)$ (Medium B) for determination of aromatase activity. For cAMP measurements, aliquants of cells $\left(100-200 \times 10^{3}\right.$ cells $)$ in $0.5 \mathrm{ml}$ DBS-BSA were added to a series of $10 \times 75 \mathrm{~mm}$ plastic test tubes at $4^{\circ} \mathrm{C}$. Ovine FSH (NIAMDD-oFSH-S16) or ovine LH (NIAMDD-oLH-S24) was added in 0.5 ml DBS-BSA at $4^{\circ} \mathrm{C}$ to give final concentrations of gonadotrophin ranging from 0 to $1 \mu \mathrm{g} / \mathrm{ml}$. The tubes were capped and incubated at $37^{\circ} \mathrm{C}$ for $1 \mathrm{~h}$ in a shaking water bath before being transferred to an $80^{\circ} \mathrm{C}$ water bath for $15 \mathrm{~min}$. Some tubes were transferred directly to the $80^{\circ} \mathrm{C}$ bath so that the endogenous cAMP content of the cells at zero time could be determined. All the tubes were frozen $\left(-20^{\circ} \mathrm{C}\right)$ until assayed for cAMP by radioimmunoassay. Preliminary studies showed that the rate of cAMP production by granulosa cells at $37^{\circ} \mathrm{C}$ was constant over $1 \mathrm{~h}$.

For determination of aromatase activity, $0.15 \mathrm{ml}$ aliquants of granulosa cells $\left(40-200 \times 10^{3}\right)$ in Medium B were incubated in 96-well microtest plates (Nunclon, Karstrup, Denmark) with $0.15 \mathrm{ml}$ Medium B containing $2000 \mathrm{ng}$ testosterone/ml for $3 \mathrm{~h}$ at $37^{\circ} \mathrm{C}$ in an humidified $(100 \%)$ incubator gassed with $5 \% \mathrm{CO}_{2}$ in air. Aromatase activity was calculated from the total amount of oestradiol present in the supernatant and the cells at the end of the incubation. The oestradiol content of cells at the beginning of the incubation was $<0.5 \mathrm{ng} / 10^{6}$ cells. Under the above assay conditions, the rate of oestradiol formation was constant for the first $3 \mathrm{~h}$.

\section{Theca interna perifusions}

To determine the ability of theca interna to secrete androstenedione in response to LH, samples of theca interna were perifused in vitro using the method described by McNatty et al. (1985) with some modifications which are included below. About $10-20 \mathrm{mg}$ (wet weight) of theca interna were placed into a glass column $(4 \times 0.7 \mathrm{~cm}$, Econo-column, BioRad Laboratories, CA, U.S.A.) containing $50 \mathrm{mg}$ Sephadex G-25 which had been prewashed for $1 \mathrm{~h}$ with a perifusion medium consisting of sterile Krebs-Ringer-bicarbonate buffer containing $1 \% \mathrm{BSA}(\mathrm{w} / \mathrm{v})$. The medium was gassed continuously with $50 \% \mathrm{O}_{2}, 45 \% \mathrm{~N}_{2}$ and $5 \% \mathrm{CO}_{2}$. All the thecae from non-atretic follicles only, irrespective of size, from at least 4 animals were pooled to ensure that sufficient tissue was available for the study (i.e. at least $10 \mathrm{mg}$ per perifusion column). The theca was perifused at $37^{\circ} \mathrm{C}$ for $2 \mathrm{~h}$ at a flow rate of $1.4 \mathrm{ml} / \mathrm{min}$ with $12-\mathrm{min}$ fractions being collected. LH (NIAMDD-oLH-S24; $8 \mathrm{ng} / \mathrm{ml}$ ) was introduced in the perifusion medium for 5 min after the tissue had first been perifused for $1 \mathrm{~h}$. At the end of the 2-h period, the tissue was fixed for histological examination and the medium from each tube was stored at $-20^{\circ} \mathrm{C}$ until assayed for androstenedione by a specific radioimmunoassay (RIA). The androstenedione output was expressed as the cumulative output (ng) per $10 \mathrm{mg}$ theca interna per $\mathrm{h}$ before and after $\mathrm{LH}$ stimulation.

\section{Cyclic AMP assay}

The DBS-BSA samples $(0.1 \mathrm{ml})$ together with the cAMP standards in $0.1 \mathrm{ml}$ DBS-BSA were assayed directly or after acetylation (Harper \& Brooker, 1975) by a specific RIA methodology described elsewhere (McNatty et al., 1986a).

The cAMP antiserum (Dr A. R. La Barbera, North Western University, Chicago, IL, U.S.A.) was made up in sodium acetate buffer $(0.05 \mathrm{M}, \mathrm{pH} 6.5)+0 \cdot 1 \%(\mathrm{w} / \mathrm{v}) \mathrm{BSA}$ and $0.1 \mathrm{ml}$ aliquants were added to the assay tubes to a final dilution of 1:45000 for non-acetylated samples and of 1:30 000 for acetylated samples. The cross-reactions of AMP, ADP, ATP, cGMP and dibutryl cAMP were all $<0.005 \%$.

The radioactive label was prepared by iodinating $2^{\prime}, 0$-monosuccinyl adenosine $3^{\prime}, 5^{\prime}$-cyclic monophosphate tyrosyl methyl ester (Sigma Chemicals, St Louis, MO, U.S.A.) to a specific activity of $120-150 \mu \mathrm{Ci} / \mu \mathrm{g}$. About $10000 \mathrm{c.p.m}$. iodinated cAMP derivative in $0.1 \mathrm{ml}$ sodium acetate buffer $(0.05 \mathrm{M}, \mathrm{pH} 6.5)$ containing $3 \%$ BSA (w/v) were added to each assay tube.

The cAMP results were expressed as pmol cAMP $/ 10^{6}$ granulosa cells. The limit of detection was $0 \cdot 1$ pmol cAMP $/ 10^{6}$ cells. The intra- and inter-assay coefficients of variation were $8 \%$ and $14 \%$ respectively.

\section{Steroid assays}

Oestradiol and androstenedione were assayed directly in diluted (10-200-fold with $0 \cdot 1 \mathrm{M}$-phosphate-buffered saline, PBS, $\mathrm{pH} 7.2$ ) aliquants of follicular fluid and/or undiluted aliquants of Medium B (i.e. from the aromatase assay) or Krebs-Ringer-bicarbonate solution by specific RIA procedures described elsewhere (McNatty et al., 1985). Testosterone was measured in follicular fluid after it had been diluted (10-200-fold) with PBS and extracted twice with 5 volumes of freshly redistilled diethyl ether. 
Details of the working solutions and specifications of the androstenedione (WA-965), testosterone (WA-36) and oestradiol-17 $\beta$ (WA-27) antisera are provided elsewhere (McNatty et al., 1981, 1984a). The detection limits were as follows: testosterone and oestradiol in follicular fluid, $1 \mathrm{ng} / \mathrm{ml}$; androstenedione in thecal perfusate, $0.5 \mathrm{ng} / 10 \mathrm{mg}$ theca-tube; oestradiol in the aromatase assay, $0.2 \mathrm{ng} / 10^{6}$ cells. The intra- and inter-assay coefficients of variation for all the above steroid assays were $<8 \%$ and $<15 \%$ respectively.

\section{Statistical procedures}

When appropriate, the raw, log-transformed or square-root transformed data (e.g. the follicle numbers) were subjected to analysis of variance in conjunction with the Neuman-Keuls test, unpaired two-tailed or paired Student's $t$ test.

\section{Results}

The mean \pm s.e.m. weights of the $\mathrm{F}+$ and ++ lambs at ovariectomy were $24.0 \pm 0.09(\mathrm{~N}=13)$ and $22.4 \pm 0.09 \mathrm{~kg}(\mathrm{~N}=16)$ respectively; these weights were not significantly different from one another.

\section{Ovarian characteristics}

These are summarized in Table 1 . The ovaries in $\mathrm{F}+$ ewes were significantly lighter $(P<0 \cdot 01)$ than those in ++ ewes but they contained on average 1.7 times more follicles ( $\geqslant 1 \mathrm{~mm}$ diam.). The increase was due entirely to follicles in the 1-1.5 mm diameter range. The major reason for the ovaries in ++ ewes being heavier than in $\mathrm{F}+$ ewes was that they contained conspicuously more interstitial/ stromal tissue. None of the ovaries in any of the lambs contained corpora lutea or corpora albicantia

Table 1. Ovarian characteristics in Booroola lambs $(\mathrm{N})$ at 3 months of age

\begin{tabular}{|c|c|c|c|c|c|c|c|c|}
\hline \multirow[b]{2}{*}{ Genotype } & \multirow{2}{*}{$\begin{array}{l}\text { Ovarian } \\
\mathrm{wt}^{*}(\mathrm{~g})\end{array}$} & \multirow[b]{2}{*}{ Follicles $\dagger$} & \multirow{2}{*}{$\begin{array}{c}\text { Follicle no. } \ddagger \\
\text { (> }>\text { mm diam.) }\end{array}$} & \multicolumn{5}{|c|}{ Follicle numbers + with respect to diameters (mm) } \\
\hline & & & & $1-1 \cdot 5$ & $2-2 \cdot 5$ & $3-3.5$ & $4-4 \cdot 5$ & $\geqslant 5$ \\
\hline $\begin{array}{l}++ \\
(\mathrm{N}=16)\end{array}$ & $\begin{array}{l}0.41^{\mathrm{a}} \\
\pm 0.02\end{array}$ & $\begin{array}{c}\mathrm{T} \\
\mathrm{NA}\end{array}$ & $\begin{array}{c}17 \cdot 6^{\mathrm{a}} \\
(13 \cdot 8,21 \cdot 7) \\
10 \cdot 2^{\mathfrak{c}} \\
(7 \cdot 2,13 \cdot 8)\end{array}$ & $\begin{array}{c}9 \cdot 7^{\mathrm{a}} \\
(7 \cdot 8,11 \cdot 8) \\
5 \cdot 4^{\mathrm{c}} \\
(3 \cdot 5,7 \cdot 6)\end{array}$ & $\begin{array}{c}5 \cdot 1 \\
(2 \cdot 7,8 \cdot 1) \\
3 \cdot 0 \\
(1 \cdot 4,5 \cdot 1)\end{array}$ & $\begin{array}{c}1 \cdot 1 \\
(0 \cdot 5,1 \cdot 7) \\
0 \cdot 6 \\
(0 \cdot 2,1 \cdot 1)\end{array}$ & $\begin{array}{c}0 \cdot 3 \\
(0 \cdot 1,0 \cdot 7) \\
0 \cdot 2 \\
(0,0 \cdot 5)\end{array}$ & $\begin{array}{c}0 \cdot 3 \\
(0 \cdot 1,0 \cdot 5) \\
0 \cdot 1 \\
(0,0 \cdot 3)\end{array}$ \\
\hline $\begin{array}{l}F+ \\
(N=13)\end{array}$ & $\begin{array}{l}0.29^{\mathrm{b}} \\
\pm 0.01\end{array}$ & $\begin{array}{c}\text { T } \\
\text { NA }\end{array}$ & $\begin{array}{c}29 \cdot 4^{\mathrm{b}} \\
(23 \cdot 7,35 \cdot 2) \\
17 \cdot 6^{\mathrm{d}} \\
(13 \cdot 5,22 \cdot 4)\end{array}$ & $\begin{array}{c}22 \cdot 6^{\mathrm{b}} \\
(17 \cdot 2,28 \cdot 7) \\
13 \cdot 8^{\mathrm{d}} \\
(10 \cdot 5,17 \cdot 7)\end{array}$ & $\begin{array}{c}4 \cdot 5 \\
(2 \cdot 4,7 \cdot 2) \\
2 \cdot 2 \\
(0 \cdot 6,4 \cdot 5)\end{array}$ & $\begin{array}{c}0.9 \\
(0 \cdot 5,1 \cdot 4) \\
0.9 \\
(0 \cdot 5,1 \cdot 4)\end{array}$ & $\begin{array}{c}0 \cdot 3 \\
(0,0 \cdot 7) \\
0 \cdot 2 \\
(0,0 \cdot 6)\end{array}$ & 0 \\
\hline
\end{tabular}

${ }^{*}$ Mean \pm s.e.m. of the mean weight of an individual ovary per lamb.

$\uparrow \mathrm{T}=$ total no. of follicles/lamb; NA = total no. of non-atretic follicles/lamb.

$\ddagger$ Mean ( $95 \%$ confidence limits) of follicle numbers per lamb; these values are the back-transformed means (and limits) derived from square-root transformed data.

a $v s b, c v s \mathrm{~d}=P<0.01$ (Student's $t$ test).

The number of granulosa cells in the different-sized non-atretic follicles with respect to genotype are summarized in Table 2. No significant genotypic differences in cell number were noted at each follicular diameter. However, the largest follicles in ++ lambs (i.e. $\geqslant 5 \mathrm{~mm}$ diam.) contained on average 2.8 times more cells than did the largest follicles present in $\mathrm{F}+$ lambs.

\section{FSH stimulation of cAMP production by granulosa cells}

Genotype and follicular diameter had no effect on the granulosa-cell cAMP response to different doses of FSH (i.e. 0, 10, 100 or $1000 \mathrm{ng} / \mathrm{ml}$ ). Also, there was no significant cAMP response by 
Table 2. The number of granulosa cells $\left(\times 10^{-6}\right)$ in non-atretic ovarian follicles of Booroola lambs with respect to follicle diameter and genotype

\begin{tabular}{|c|c|c|}
\hline \multirow{2}{*}{$\begin{array}{l}\text { Follicle } \\
\text { diam. }(\mathrm{mm})\end{array}$} & \multicolumn{2}{|c|}{ Genotype } \\
\hline & ++ & $\mathrm{F}+$ \\
\hline$\geqslant 5$ & $\begin{array}{c}3 \cdot 4(2 \cdot 3,4 \cdot 6) \\
{[4]}\end{array}$ & (no follicles) \\
\hline 44.5 & $\begin{array}{c}2 \cdot 2(1 \cdot 5,3 \cdot 0) \\
{[4]}\end{array}$ & $\begin{array}{c}1 \cdot 2(0 \cdot 3,2 \cdot 8) \\
{[3]}\end{array}$ \\
\hline 3-3.5 & $\begin{array}{c}1 \cdot 2(0 \cdot 8,1 \cdot 5) \\
{[7]}\end{array}$ & $\begin{array}{c}1 \cdot 1(0 \cdot 5,1 \cdot 9) \\
{[5]}\end{array}$ \\
\hline $2-2.5$ & $\begin{array}{c}0.6(0 \cdot 5,0 \cdot 9) \\
{[13]}\end{array}$ & $\begin{array}{c}0 \cdot 6(0 \cdot 4,0 \cdot 8) \\
{[10]}\end{array}$ \\
\hline $1-1.5$ & $\begin{array}{c}0 \cdot 4(0 \cdot 3,0 \cdot 6) \\
{[15]}\end{array}$ & $\begin{array}{c}0 \cdot 4(0 \cdot 3,0 \cdot 5) \\
{[13]}\end{array}$ \\
\hline
\end{tabular}

Table 3. FSH-stimulated production of cAMP ( $\mathrm{pmol} / 10^{6}$ cells $/ \mathrm{h}$ ) by granulosa cells from Booroola lambs with respect to follicular health and dose of FSH

\begin{tabular}{lccccc}
\hline $\begin{array}{l}\text { Follicular } \\
\text { health } \\
(n)\end{array}$ & \multicolumn{5}{c}{ FSH dose $(\mathrm{ng} / \mathrm{ml})$} \\
\cline { 2 - 6 } & 0 & 1 & 10 & 100 & 1000 \\
\hline $\begin{array}{l}\text { Non-atretic } \\
\text { (46) }\end{array}$ & $0 \cdot 4^{\mathrm{a}}$ & $0 \cdot 4^{\mathrm{a}}$ & $0 \cdot 7^{\mathrm{b}}$ & $2 \cdot 2^{\mathrm{c}}$ & $6 \cdot 9^{\mathrm{d}}$ \\
Atretic & $(0 \cdot 3,0 \cdot 5)$ & $(0 \cdot 3,0 \cdot 5)$ & $(0 \cdot 6,0 \cdot 9)$ & $(1 \cdot 9,2 \cdot 5)$ & $(5 \cdot 6,8 \cdot 3)$ \\
$(7)$ & $0 \cdot 3^{\mathrm{a}}$ & $0 \cdot 4^{\mathrm{a}}$ & $0 \cdot 4^{\mathrm{a}}$ & $0 \cdot 7^{\mathrm{a}}$ & $0 \cdot 8^{\mathrm{a}}$ \\
& $(0 \cdot 1,0 \cdot 4)$ & $(0 \cdot 1,0 \cdot 6)$ & $(0 \cdot 2,0 \cdot 5)$ & $(0 \cdot 5,1 \cdot 0)$ & $(0 \cdot 3,1 \cdot 3)$ \\
\hline
\end{tabular}

Values are geometric means (and 95\% confidence limits) for the no. of pools of cells tested $(n)$.

Values in rows or columns with different alphabetical superscripts are significantly different from one another, a $v s \mathrm{~b}=P<0.05$; a $v s \mathrm{c}$, a $v s \mathrm{~d}, \mathrm{~b} v s \mathrm{~d}$, c vs $\mathrm{d}=P<0.01$ (ANOVA, Neuman-Keuls test on log-transformed data).

granulosa cells from atretic follicles to different doses of FSH (Table 3). However, in cells from non-atretic follicles, FSH doses of 10,100 and $1000 \mathrm{ng} / \mathrm{ml}$ caused a significant stepwise increase in cAMP production compared to that achieved at FSH doses of 0 and $1 \mathrm{ng} / \mathrm{ml}$ (Table 3).

\section{LH stimulation of cAMP production by granulosa cells}

The production of cAMP by granulosa cells from non-atretic follicles from Booroola lambs due to LH stimulation was influenced by follicular diameter and genotype (Table 4). For example, in ++ lambs none of the cell preparations from the lambs with follicles between 1 and $4.5 \mathrm{~mm}$ in diameter responded to $\mathrm{LH}$ to produce cAMP. In contrast, all of the $4++$ lambs with non-atretic follicles $\geqslant 5 \mathrm{~mm}$ diameter contained cells which responded to the two LH doses tested (i.e. 10 and $1000 \mathrm{ng} / \mathrm{ml}$ ). In F + lambs, none of the cell preparations from the follicles between 1 and $2.5 \mathrm{~mm}$ in 
Table 4. LH-stimulated production of cAMP $\left(\mathrm{pmol} / 10^{\circ}\right.$ cells/h) by granulosa cells from Booroola lambs $(\mathrm{N})$ with respect to Booroola genotype, follicular diameter and dose of $\mathrm{LH} \dagger$

\begin{tabular}{|c|c|c|c|c|}
\hline \multirow{2}{*}{$\begin{array}{l}\text { Booroola } \\
\text { genotype } \\
(\mathrm{N})\end{array}$} & \multirow{2}{*}{$\begin{array}{l}\text { Follicular } \\
\text { diam. } \\
\text { (mm) }\end{array}$} & \multicolumn{3}{|c|}{ LH dose $(\mathrm{ng} / \mathrm{ml})$} \\
\hline & & 0 & 10 & 1000 \\
\hline $\begin{array}{c}++ \\
(16)\end{array}$ & $1-4 \cdot 5$ & $\begin{array}{c}0 \cdot 4^{\mathrm{a}} \\
(0 \cdot 3,0 \cdot 5)\end{array}$ & $\begin{array}{c}0 \cdot 5^{\mathrm{a}} \\
(0 \cdot 4,0 \cdot 6)\end{array}$ & $\begin{array}{c}0 \cdot 6^{\mathrm{a}} \\
(0 \cdot 4,0 \cdot 9)\end{array}$ \\
\hline $\begin{array}{l}++ \\
(4)\end{array}$ & $\geqslant 5$ & $\begin{array}{c}0 \cdot 3^{\mathrm{a}} \\
(0 \cdot 2,0 \cdot 4)\end{array}$ & $\begin{array}{c}\mathrm{I} \cdot 1^{\mathrm{b}} \\
(0 \cdot 7,1 \cdot 5)\end{array}$ & $\begin{array}{c}4 \cdot 7^{\mathrm{c}} \\
(2 \cdot 3,8 \cdot 0)\end{array}$ \\
\hline $\begin{array}{l}\mathrm{F}+ \\
\text { (13) }\end{array}$ & $1-2 \cdot 5$ & $\begin{array}{c}0 \cdot 5^{\mathrm{a}} \\
(0 \cdot 3,0 \cdot 7)\end{array}$ & $\begin{array}{c}0.6^{\mathbf{a}, \mathbf{b}} \\
(0 \cdot 5,0 \cdot 8)\end{array}$ & $\begin{array}{c}0.6^{\mathrm{a}} \\
(0 \cdot 4,0 \cdot 9)\end{array}$ \\
\hline $\begin{array}{l}F+ \\
(4)\end{array}$ & $3-4 \cdot 5$ & $\begin{array}{c}0 \cdot 3^{\mathrm{a}} \\
(0 \cdot 2,0 \cdot 4)\end{array}$ & $\begin{array}{c}1 \cdot 4^{b} \\
(0 \cdot 5,3 \cdot 1)\end{array}$ & $-\ddagger$ \\
\hline
\end{tabular}

$\uparrow$ Values are geometric means (and 95\% confidence limits) of mean values from each lamb the total number of which is represented by $\mathrm{N}$. The number of pools of cells per lamb varied from 1 to 3 . None of the follicles of $1-4.5 \mathrm{~mm}$ diam. range in ++ lambs and none of those in the $1-2.5 \mathrm{~mm}$ diam. range in $F+$ lambs contained granulosa cells which responded to $\mathrm{LH}$ to produce more cAMP than the controls.

For each genotype, values in rows or columns not sharing an alphabetical superscript are significantly different from one another (ANOVA, Neuman-Keuls test), a vs $\mathrm{b}=P<0.05$; $\mathrm{a}$ vs $\mathrm{c}$, b vs $\mathrm{c}=P<0.01$.

$\$$ Not tested.

diameter responded to LH to produce cAMP whereas 3 of the 4 lambs with non-atretic follicles between 3 and $4.5 \mathrm{~mm}$ diameter contained cells which responded to $10 \mathrm{ng} \mathrm{LH} / \mathrm{ml}$ to produce a greater level of cAMP than did those preparations not exposed to LH (Table 4). The influence of LH on cAMP production by cells from atretic follicles was not tested because of insufficient cells.

\section{Granulosa cell aromatase activity with respect to Booroola genotype and follicle size}

These data for cells from non-atretic follicles are summarized in Fig. 1. In both genotypes aromatase activity increased with increasing follicular diameter. In $F+$ lambs, aromatase activity in cells from follicles of $3-3.5 \mathrm{~mm}$ diameter was significantly greater $(P<0.01)$ than that in cells from follicles of $1-1.5$ and $2-2.5 \mathrm{~mm}$ diameter. In ++ lambs, the highest mean level of aromatase activity was present in $\geqslant 4 \mathrm{~mm}$ diameter follicles, but because of the wide variation in activity there was no significant difference with respect to follicular diameter. In 3-3.5 mm follicles there was a genotypic difference in aromatase activity with significantly higher $(P<0.05)$ levels in cells from $\mathrm{F}+$ lambs. In cells from atretic follicles, aromatase activity was uniformly low across the genotypes; the geometric mean (and $95 \%$ confidence limits) being $0.5(0 \cdot 3,0 \cdot 7) \mathrm{ng} / 10^{6}$ cells $/ 3 \mathrm{~h}$.

\section{LH-induced thecal androstenedione synthesis}

From the $16++$ and $13 \mathrm{~F}+$ lambs, 4 and 3 pools of theca interna respectively were recovered to test the influence of LH on thecal androstenedione synthesis. Histologically, the purity of the theca interna in the isolated tissues was estimated to be $63 \pm 4 \%$ (means \pm s.e.m.; $n=7$ ); the major contaminant was theca externa or stromal tissue. Very few granulosa cells $(<4$ cells $/ 5 \mu \mathrm{m}$ section) were noted in the preparations. No obvious genotypic differences were noted and so the 


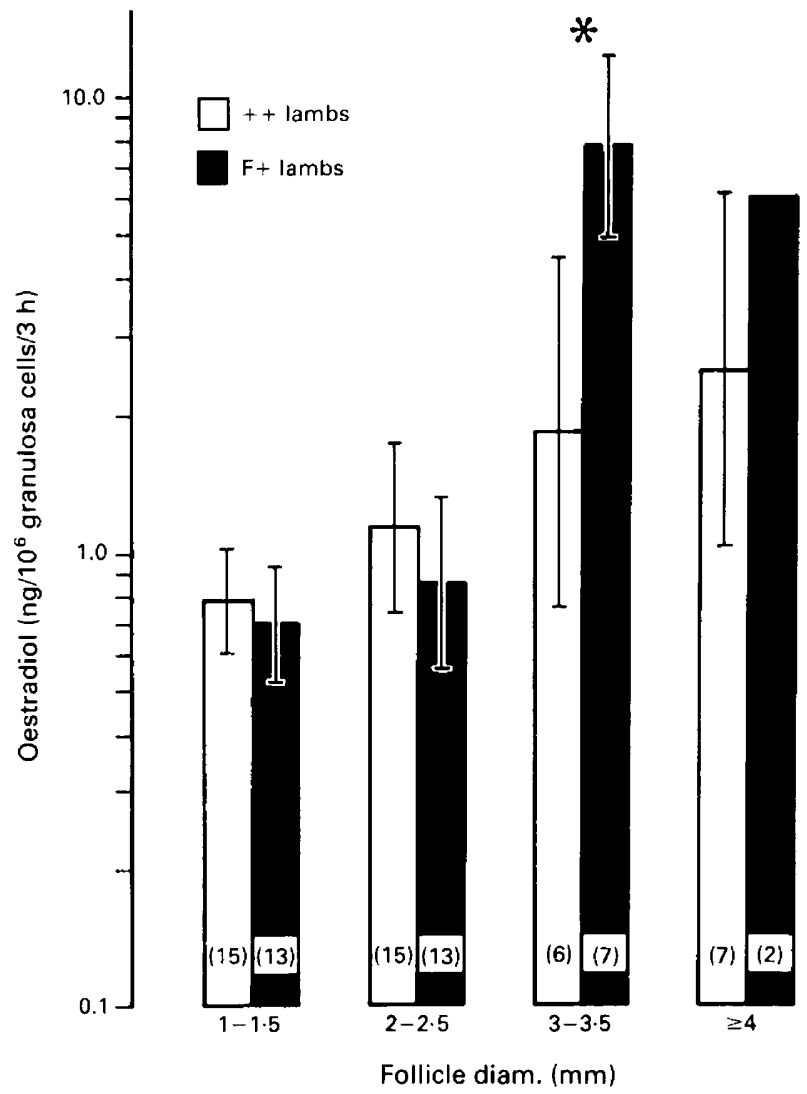

Fig. 1. Aromatase activity in granulosa cells from non-atretic follicles of different sizes from $\mathrm{F}+$ and ++ Booroola lambs. Results are geometric means of mean values from each lamb with the vertical bars representing $95 \%$ confidence limits. Numbers in parentheses refer to the number of ewes from which granulosa cells are studied. ${ }^{*}(P<0.05$ unpaired Student's $t$ test $)$ compared with value for ++ lambs.

results were pooled across the genotypes. The geometric means (and 95\% confidence limits) for androstenedione output before and after LH stimulation were $7(5,10)$ and $17(11,26) \mathrm{ng} / 10 \mathrm{mg}$ theca interna/h respectively; the output after LH stimulation was significantly higher $(P<0.01$; paired $t$ test) than beforehand.

\section{Steroid concentrations in follicular fluid}

The data summarized in Table 5 include the results from non-atretic and atretic follicles since no overall significant differences were noted with respect to follicular health. For both genotypes, there was no significant influence of follicular diameter on the concentration of testosterone or oestradiol. The only exception to this was for testosterone in $\geqslant 5 \mathrm{~mm}$ follicles from ++ ewes; in this instance the testosterone concentrations were significantly lower than in follicles of $1-2.5$ $(P<0.01)$ and $3-4.5 \mathrm{~mm}$ diameter $(P<0.01)$. In follicles of $1-2.5$ and $3-4.5 \mathrm{~mm}$ diameter, the concentrations of testosterone were significantly higher in those from ++ than from $\mathrm{F}+$ lambs. For oestradiol, no significant genotypic differences were noted. In the ++ and F+ ewes, 6 $(37 \cdot 5 \%)$ and $5(38.4 \%)$ of the animals respectively contained 'oestrogenic' follicles (i.e. $50 \mathrm{ng}$ oestradiol/ml follicular fluid; see McNatty et al., 1985). In one animal from each of these genotypes there were two such 'oestrogenic' follicles. All 'oestrogenic' follicles had been classified as non-atretic. 
Table 5. Steroid concentrations in follicular fluid of different sized ovarian follicles of Booroola lambs with respect to genotype

\begin{tabular}{lcccc}
\hline \multirow{2}{*}{ Genotype } & \multirow{3}{c}{ Sollicular diameter $(\mathrm{mm})$} \\
\cline { 3 - 5 } & Steroid & $1-2 \cdot 5$ & $3-4 \cdot 5$ & $\geqslant 5$ \\
\hline++ & Testosterone & $86^{*}$ & $80^{*}$ & 38 \\
& & $(65,112)$ & $(50,129)$ & $(18,20)$ \\
$\mathrm{F}+$ & Testosterone & 44 & 33 & - \\
& & $(28,68)$ & $(19,56)$ & \\
++ & Oestradiol & 16 & 19 & 18 \\
$\mathrm{~F}+$ & Oestradiol & $(9,28)$ & $(9,38)$ & $(5,59)$ \\
& & 13 & 21 & - \\
\hline
\end{tabular}

\footnotetext{
Values are geometric means (and 95\% confidence limits) of mean values from each lamb, the total number of which is represented by $\mathrm{N}$. For individual lambs, the number of replicates varied from 1 to 4 . For ++ lambs, $N=16,13$ and 5 for $1-2 \cdot 5,3-4 \cdot 5$ and $\geqslant 5 \mathrm{~mm}$ follicles respectively. For $\mathrm{F}+$ lambs, $\mathrm{N}=13$ and 10 for $1-2.5$ and $3-4.5 \mathrm{~mm}$ follicles respectively.

$* P<0.025$ compared to testosterone concentrations in $\mathrm{F}+$ ewes.
}

\section{Discussion}

These results show that the Booroola F-gene has a major influence on the structure and function of ovaries several months before the onset of puberty. In spring-born Booroola lambs with or without the F-gene, the first ovulations normally occur after 7 months of age (Davis \& Johnstone, 1985). The main feature of the ovaries of the $\mathrm{F}+$ Booroola lambs was the large numbers of follicles $(\geqslant 1 \mathrm{~mm}$ diam.) whereas in the ++ Booroola lambs the main feature was the large amounts of interstitial/stromal tissue.

The distribution of follicle sizes was characteristic of those of mature Booroola ewes. For example, large follicles $(\geqslant 5 \mathrm{~mm}$ diam.) were sometimes present in ++ lambs but were absent in $\mathrm{F}+$ lambs. However, the presence of 2.3 times more follicles of $1-1.5 \mathrm{~mm}$ diameter in $\mathrm{F}+$ than in ++ lambs was not observed in mature ewes (see McNatty et al., 1985, 1986b).

The mean numbers of granulosa cells in the non-atretic follicles with respect to follicular diameter were about $70 \%$ of those found in mature ewes (McNatty et al., 1985, 1986b). In the present study, the number of observations on cell numbers for follicles $\geqslant 3 \mathrm{~mm}$ diameter was limited (Table 1) because follicles of these sizes were not present in all lambs. Nevertheless, the numbers of granulosa cells in the largest follicles (i.e. $\geqslant 3 \mathrm{~mm}$ diam.) for $\mathrm{F}+$ lambs were similar to those for mature ewes in that they rarely exceeded $3 \times 10^{6}$. Moreover, the number of granulosa cells in the largest follicles of ++ lambs (i.e. $\geqslant 4 \mathrm{~mm}$ diam.) normally exceeded $3 \times 10^{6}$ which was also true of ++ ewes (see also McNatty et al., 1985, 1986b).

From several studies on ovaries from lambs between 10 and 32 weeks of age it has been noted that they are able to secrete steroids, ovulate and produce fertilizable ova in response to PMSG and/or hCG (Mansour, 1959; Land \& McGovern, 1968; Trounson et al., 1977). The present study shows that lambs at 12 weeks of age have granulosa cells with functional FSH receptors as judged by their cAMP responses to exogenous FSH (Table 3), and theca interna cells with functional LH receptors as judged by their androstenedione responses to exogenous LH (see 'Results'). Moreover, the presence of some testosterone and oestradiol in follicular fluid at concentrations similar to those in mature ewes during the luteal phase or anoestrus (McNatty et al., 1984a), as well as the presence of aromatase activity in granulosa cells, indicates that at least some of the ovarian follicles in lambs 
can respond to gonadotrophins and synthesize steroids in a manner similar to that observed in mature ewes (see also Trounson et al., 1977; Tassell et al., 1978; Tassell \& Kennedy, 1980). Furthermore, the development of functional $\mathrm{LH}$ receptors in granulosa cells of the largest nonatretic follicles from ewes of both Booroola genotypes (i.e. as judged by the LH-induced cAMP response) supports the notion that, even in prepubertal lambs, ovarian follicles may sometimes mature to a preovulatory stage.

In mature ewes, granulosa cell preparations from follicles ( $\geqslant 3-4 \mathrm{~mm}$ diam.) of $\mathrm{F}+$ animals $(\mathrm{N}=21)$ produced more cAMP in response to $\mathrm{FSH}$ than did cells from ++ animals $(\mathrm{N}=14$; Henderson et al., 1985). Also, in mature ewes, the FSH-induced cAMP response in $\mathrm{F}+$ and ++ ewes was significantly higher in $\geqslant 3 \mathrm{~mm}(\mathrm{~N}=34)$ and $\geqslant 4 \mathrm{~mm}(\mathrm{~N}=42)$ diameter follicles respectively than in follicles of smaller diameter from each genotype. In the present study, there were no significant genotypic differences in FSH-induced cAMP synthesis and there was also no significant effect of follicle diameter. However, in view of the logarithmic nature of the cAMP responses to FSH, the number of follicles $\geqslant 3 \mathrm{~mm}$ and $\geqslant 4 \mathrm{~mm}$ diameter for each genotype in the present study (i.e. 4 and 7 for $\mathrm{F}+$ and ++ lambs, respectively) was too small for any meaningful comparison of FSH responses of granulosa cells between lamb genotypes or between lambs and ewes. There was, however, clear evidence from the present study, and from Henderson et al. (1985), that granulosa cells from atretic follicles do not respond well to FSH with respect to cAMP synthesis. Presumably this may partly explain the finding that cells from atretic follicles of Booroola lambs have low aromatase activity as stimulation of this enzyme activity is mediated via cAMP (Hillier, 1981).

Although the sample size was small, there was convincing evidence from the present study for a genotypic difference in the size of the follicle in which granulosa cells develop a responsiveness to LH as has been shown in mature ewes (Henderson et al., 1985). In the present study $75 \%$ of the cell preparations from follicles of $3-4.5 \mathrm{~mm}$ diameter from $\mathrm{F}+$ lambs responded to $\mathrm{LH}$ to produce cAMP whereas none of the comparably sized follicles of ++ lambs responded. In the latter genotype, only follicles $\geqslant 5 \mathrm{~mm}$ diameter responded to $\mathrm{LH}$ to produce cAMP.

The presence of significantly higher concentrations of testosterone in follicular fluid in ++ lambs compared to that in comparable-sized follicles in $\mathrm{F}+$ lambs is not inconsistent with those for mature ++ and F + ewes (McNatty et al., 1985). In the ewes, the presence of high testosterone could be explained on the basis that the $\mathrm{F}+$ ewes had significantly higher concentrations of oestradiol in follicular fluid. This does not, however, explain the different testosterone values in the lambs since the oestradiol concentrations were similar between the genotypes. In the absence of information on the patterns of gonadotrophin secretion and the concentrations of other steroids in follicular fluid, further study will be needed to clarify this point. The presence of significantly higher aromatase activity in granulosa cells from $3-3.5 \mathrm{~mm}$ follicles of $F+$ lambs compared to those of ++ lambs is consistent with the findings for mature ewes (McNatty et al., 1985).

The reasons why the above structural and functional differences occur between $\mathrm{F}+$ and ++ Booroola lambs is unclear. Booroola lambs have been recorded with higher FSH and sometimes higher LH concentrations at 30 days of age compared to those in control Merino lambs (Bindon \& Turner, 1974; Findlay \& Bindon, 1976; Bindon et al., 1985). However, these differences in gonadotrophin secretion were not observed in the above lambs at 60 or 110 days of age (Bindon et al., 1985) and it remains unclear whether gonadotrophin differences actually exist between Booroola lambs with and without the gene. The presence of higher granulosa-cell aromatase activity and functional $\mathrm{LH}$ receptors in granulosa cells of smaller-sized follicles of $F+$ lambs relative to those in ++ lambs is not inconsistent with the view that prepubertal Booroola $F+$ lambs have higher plasma concentrations of FSH than ++ lambs. However, support for this notion will require further study.

We thank Mr G. Davis of the Invermay Agricultural Research Centre for supplying the lambs used in this study, Norma Hudson and Kathy Ball for supervision and care of the animals at Wallaceville, and Dr M. C. Roberts for statistical advice. Ovine gonadotrophins were generously 
provided by the National Hormone and Pituitary Program, National Institute of Arthritis, Diabetes and Digestive and Kidney Diseases, Maryland, U.S.A. and the cAMP antiserum by Dr A. R. La Barbera, Northwestern University, Chicago, Illinois, U.S.A.

\section{References}

Bindon, B.M. (1984) Reproductive biology of the Booroola Merino sheep. Aust. J. biol. Sci. 37, $163-189$.

Bindon, B.M. \& Turner, H.N. (1974) Plasma LH of the prepubertal lamb: a possible early indicator of fecundity. J. Reprod. Fert. 39, 85-88.

Bindon, B.M., Findlay, J.K. and Piper, L.R. (1985) Plasma FSH and LH in prepubertal Booroola ewe lambs. Aust. J. biol. Sci. 38, 215-220.

Davis, G.H. \& Johnstone, P.D. (1985) Ovulation response to pregnant mares' serum gonadotrophin in prepubertal ewe lambs of different Booroola genotypes. Anim. Reprod. Sci. 9, 145-151.

Davis, G.H., Montgomery, G.W., Allison, A.J., Kelly, R.W. \& Bray, A.R. (1982) Segregation of a major gene influencing fecundity of progeny of Booroola sheep. N.Z. Jl agric. Res. 25, 525-529.

Findlay, J.K. \& Bindon, B.M. (1976) Plasma FSH in Merino lambs selected for fecundity. J. Reprod. Fert. 46, 515-516.

Harper, J.F. \& Brooker, G. (1975) Femtomole sensitive radioimmunoassay for cyclic AMP and cyclic GMP after $2^{\prime} 0$-acetylation by acetic anhydride in aqueous solution. J. cyclic Nucleotide Res. 1, 207-218.

Henderson, K.M., Kieboom, L.E., McNatty, K.P., Lun, S. \& Heath, D.A. (1985) Gonadotrophin-stimulated cyclic AMP production by granulosa cells from Booroola $\times$ Romney ewes with and without a fecundity gene. J. Reprod. Fert. 75, 111-120.

Hillier, S.G. (1981) Regulation of follicular oestrogen biosynthesis: a survey of current concepts. J. Endocr. 89, 3p-18p.

Land, R.B. \& McGovern, P.K. (1968) Ovulation and fertilization in the lamb. J. Reprod. Fert. 15, 325-327.

Mansour, A.M. (1959) The hormonal control of ovulation in the immature lamb. J. agric. Sci., Camb. 52, 87-93.

McNatty, K.P., Gibb, M., Dobson, C., Thurley, D.C. \& Findlay, J.K. (1981) Changes ir the concentrations of gonadotrophic and steroidal hormones in the antral fluid of ovarian follicles throughout the oestrous cycle of the sheep. Aust. J. biol. Sci. 34, 67-80.

McNatty, K.P., Hudson, N., Henderson, K.M., Lun, S., Heath, D.A., Gibb, M., Ball, K., McDiarmid, J.M. \& Thurley, D.C. (1984a) Changes in gonadotrophin secretion and ovarian antral follicular activity in seasonally breeding sheep throughout the year. $J$. Reprod. Fert. 70, 309-321.
McNatty, K.P., Heath, D.A., Lun, S., Fannin, J. McDiarmid, J.M. \& Henderson, K.M. (1984b) Steroidogenesis by bovine theca interna in an in vitro perifusion system. Biol. Reprod. 30, 159-170.

McNatty, K.P., Henderson, K.M., Lun, S., Heath, D.A., Ball, K., Hudson, N.L., Fannin, J., Gibb, M., Kieboom, L.E. \& Smith, P. (1985) Ovarian activity in Booroola $\times$ Romney ewes which have a major gene influencing their ovulation rate. J. Reprod. Fert. 73, 109-120.

McNatty, K.P., Kieboom, L.E., McDiarmid, J., Heath, D.A. \& Lun, S. (1986a) Adenosine cyclic, 3',5'-monophosphate and steroid production by small ovarian follicles from Booroola ewes with and without a fecundity gene. J. Reprod. Fert. 76, 471-480.

McNatty, K.P., Lun, S., Heath, D.A., Ball, K., Smith, P., Hudson, N.L., McDiarmid, J., Gibb, M. \& Henderson, K.M. (1986b) Differences in ovarian activity in Booroola $\times$ Merino ewes which were homozygous, heterozygous and non-carriers of a major gene influencing their ovulation rate. $J$. Reprod. Fert. 77, 193-205.

McNatty, K.P., O'Keeffe, L.E., Henderson, K.M., Heath, D.A. \& Lun, S. (1986c) ${ }^{125}$ I-Labelled hCG binding characteristics in theca interna and other tissues from Romney ewes and from Booroola $\times$ Romney ewes with and without a major gene influencing their ovulation rate. J. Reprod. Fert. 77, 477-488.

Tassell, R. \& Kennedy, J.P. (1980) Early follicular development and atretic changes in the ovary of the lamb-Fine structure and histochemistry. Aust. J. biol. Sci. 33, 675-687.

Tassell, R., Chamley, W.A. \& Kennedy, J.P. (1978) Gonadotrophin levels and ovarian development in the neonatal ewe lamb. Aust. J. biol. Sci. 31, 267-273.

Tassell, R.J., Kennedy, J.P., Bindon, B.M. \& Piper, L.R. (1983) Ovarian follicles of new born Merino lambs from genetic lines which differ in fecundity. Aust. $J$. biol. Sci. 36, 351-355.

Trounson, A.O., Willadsen, S.M. \& Moor, R.M. (1977) Reproductive function in prepubertal lambs: ovulation, embryo development and ovarian steroidogenesis. J. Reprod. Fert. 49, 69-75. 